\title{
Company personnel policy as part of new management approaches in globalization
}

\author{
Zuzana Stofkova ${ }^{1, *}$, Dagmar Hraskova ${ }^{1}$ \\ ${ }^{1}$ University of Zilina, Faculty of Operation and Economics of Transport and Communication, \\ Department of Economics, 01026 Zilina, Slovakia
}

\begin{abstract}
Human resources are a determining factor in ensuring business prosperity. Skilled, educated and motivated employees are a source of competitive advantage for businesses and they are an active part of the business. They secure the production of goods, the provision of services, the fulfillment of objectives and the definition of strategies, how to achieve these goals. Recruiting and selecting of qualified employees is a challenging process at the time of globalization. It is particularly important for candidates to have a combination of soft skills, technical and digital know-how. The company has to deal with the issue of occupation of jobs by suitable employees and at the same time the conditions have to be created in order to maintain and stabilize employees. They must constantly strive to maintain, respectively increasing employee satisfaction. The paper deals with the issue of recruitment and selection of employees as part of the personnel policy of the company, based on the knowledge that the inefficient process of filling vacancies can negatively affect the course of other personnel activities, but also the operation of the whole company and its profitability. The paper includes an analysis of the process of filling jobs in the company. In the paper an expert interview and survey is carried out, based on which effective approaches in recruiting and selecting employees in the selected enterprise are proposed.
\end{abstract}

\section{Introduction}

In the current labour market, there are job-seekers who represent the supply of labour and employers that influence labour demand; i.e. by employees.

The labour market is that even today, which is characterized by globalization, some companies cannot find suitable employees for their jobs. The unemployment rate may reflect two very different facts, namely an active labour market with many discharges and recruitments, or an inadaptable labour market, low recruitment rates, and a stagnant number of unemployed persons.

Companies are under increasing pressure to reduce margins and increase efficiency and are forced to produce more, with the same or less human resources, which puts much greater demands on the organization and management of human resources and of course on employees at all levels.

\footnotetext{
*Corresponding author: zuzana.stofkova@fpedas.uniza.sk
} 
In the current era of globalisation, people with the right skills has become the main source of the company's economic growth, at the same time companies cannot find suitable employees for the required jobs. With the advancement of technology, companies' demands for employees are changing at a faster pace than the population's skill structure.

In addition, the demographic evolution of society leads to a shrinking active population in developed countries. There are therefore fewer people in the labour market with adequate skills and abilities. These are the reasons why companies will need to be more active in the labour market in finding, recruiting and developing their employees, reviewing work processes and workforce structure.

Due to the transformation in the labour market, many processes are being automatized and robotized. Therefore, employees need to be digitally trained to be prepared for new jobs. The impact on individual positions varies; the most promising are IT positions, where the largest increase in the number of employees is expected. In Slovakia, the trend of increasing the number of skilled workers prevails without reducing the number of bluecollar professions, as indicated by the Labour Market Index in Slovakia. On the contrary, a decline is expected in administrative and office positions. The Intelligent Industry Concept and its Action Plan in the Slovak Republic create conditions for implementing digitization, innovative solutions and increasing competitiveness.

\section{Personnel policy in the company}

The most relevant and efficient resource for an organization lies in the human resources. An employee can be a source of income for the organization, if he provides the necessary opportunities for that individual. [1]

Successful companies consider their employees as a key resource necessary for the survival of the company. Companies can work only if they are able to ensure sufficient human resources. [2]

The labour market is the place where the demand for labour meets the offer of available positions by companies, where job applicants are considered to be customers and offer is provided by employers. There is a fight for employees between competing companies. [3]

The recruitment and selection policy is an important part of the company's personnel policy. It includes the process of filling vacancies that have been created by the company, either because of the expansion of the company or the change in the organizational structure, and the conclusion of this process is the selection of the most suitable candidate and the conclusion of an employment contract.

It is necessary to plan and then obtain a new workforce to supplement the required number of employees in the company. The process of recruiting and selecting employees of a company involves several steps.

\subsection{Recruiting and selection of employees}

Recruiting is a key phase in shaping the workforce of a company and largely decides what employees will be available to the company. Thus, it decides whether the company's objectives are met by these employees, decides on the success, prosperity and competitiveness of the company. [4]

"Hiring is a process that aims to ensure that an organization has a sufficient number of suitable jobseekers in time and that the costs of the individual activities of the process are adequate." [5] Blašková [6] defines hiring as a process, the purpose of which is to effectively present free and open job opportunities to the internal and external job potential market, thus attracting and attracting suitable and motivated job seekers (reassignment) in the company. 
The company seeks to meet the need for staff and at the same time people are looking for new jobs. In addition to new job seekers, the recruitment process may also affect the company's current employees who are interested in changing jobs or are transferred to another job position for organizational reasons. At the same time, the author describes the recruitment of employees as a "two-way communication process." The internal and external conditions influence the applicants' response to the job offer. [6]

Given the dynamic situation on the labour market, affected by tendencies such as the natural growth rate, the aging of societies, falling unemployment rates, and migration, we should expect socially responsible human resource management to be more and more frequently used as an inseparable and permanent element of the personnel strategy. [7]

Besides the internal conditions, the external recruitment process also affects the recruitment process. Koubek [4] ranks among the most important external conditions demographic, economic, social, technological and political-legislative conditions. The internal conditions of recruitment influence the individual decision-making of candidates whether they will respond to the job offer, the external conditions are objective and cannot be influenced by the company and must be taken into account in the decision-making process.

Recruitment is part of the overall process of forming the work potential of the company, staffing, which is based on personnel planning and work analysis. Subsequently, the recruitment process is followed by other personnel activities such as selection, orientation and adaptation, skills development and career management. Recruitment has to be understood as a methodologically sophisticated process that goes through several stages. The different stages of the recruitment process are illustrated in Figure 1. [8]

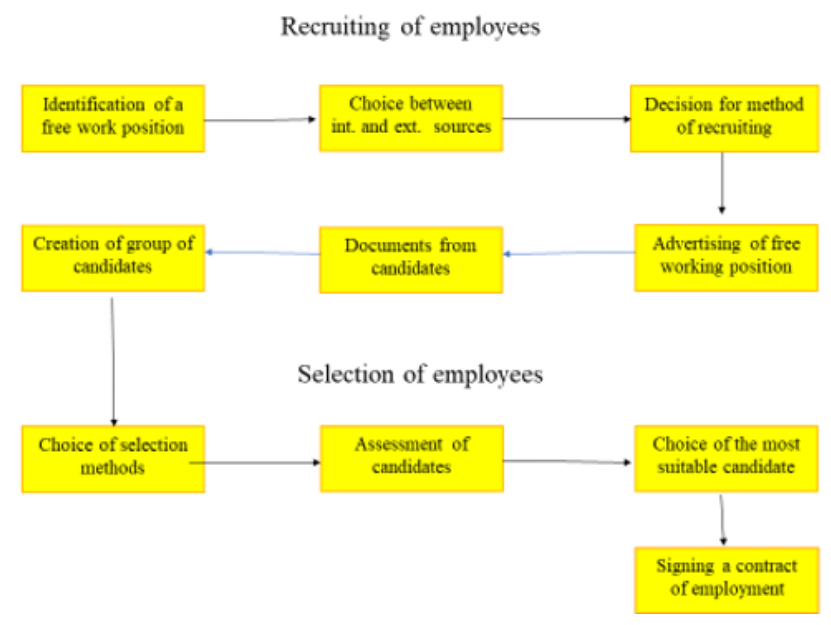

Fig. 1. The different stages of the recruitment process. Source: own processing

Therefore, the first phase of this process is to define the need to fill a vacancy, i.e. to determine the number and structure of staff, based on a staffing plan that sets out the need for staff and how it can be covered. After defining the needs of employees, it is necessary to know the essential characteristics of the job and setting requirements for employees. [9]

The second phase of the process is the selection of candidates' resources, whereby the company can decide between internal (own employees) or external resources or combine these resources. External sources of recruitment are: graduates of educational institutions, employees of other companies, free human resources at the labour market and other external resources. [8] 
The essence of the process of recruiting and selecting employees in an enterprise is to ensure that the enterprise can achieve its goals. Employees of the company are the most important source of fulfilling the goals of the company and it is therefore important to be the right people, with the right skills in the right place and at the right time.

Specific work with people's attitudes and values helps to really fire up the motivation and proactivity. [10]

\subsection{Methods of recruitment of employees}

Companies have a choice of several ways to choose the most suitable employee for the job to be filled. [5] The most commonly used methods of recruitment are online recruitment, advertising, external services, business cooperation with labour offices, referral of own employees and business cooperation with educational institutions. E-recruitment is a method of recruiting employees that can bring value to the business and can reach diverse and qualified job seekers in a cost-effective way. Through e-recuitment it is possible to reach a wider range of applicants, a cheaper and faster way than traditional advertising. [11, 12] classify own business website, work servers and social networking among the effective ways of e-recruitment.

In addition to classic methods of recruiting applicants, HR specialists when looking for employees should focus on Facebook, Google+, Pokec, Skype and YouTube. [13]

Headhunting is a modern method of recruiting, targeting and directing the job offer to a suitable candidate, mainly in filling highly professional positions. [14] Overview of the recruiting methods from internal or external sources shows Table 1.

Table 1. Overview of method of recruiting of employees

\begin{tabular}{|c|c|c|}
\hline Method & Advantages & Disadvantages \\
\hline $\begin{array}{l}\text { Web site of the } \\
\text { company }\end{array}$ & $\begin{array}{l}\text { Websites allow you to reach your } \\
\text { candidates using a business brand }\end{array}$ & $\begin{array}{l}\text { Websites require the support of } \\
\text { other media }\end{array}$ \\
\hline Job offering web site & $\begin{array}{l}\text { Job web site help to find job offers } \\
\text { and CVs }\end{array}$ & $\begin{array}{l}\text { Job web site do not satisfy } \\
\text { passive candidates }\end{array}$ \\
\hline Social networks & $\begin{array}{l}\text { Social networks make it possible to } \\
\text { stay connected }\end{array}$ & $\begin{array}{l}\text { Social networks force employers } \\
\text { and jobseekers to develop their } \\
\text { own user profiles }\end{array}$ \\
\hline Job advertisments & $\begin{array}{l}\text { Allows to reach people who are not } \\
\text { actively seeking employment }\end{array}$ & $\begin{array}{l}\text { Social networks force employers } \\
\text { and jobseekers to develop their } \\
\text { own user profiles }\end{array}$ \\
\hline $\begin{array}{l}\text { Public employment } \\
\text { agencies }\end{array}$ & $\begin{array}{l}\text { Saving time, reduce problems and } \\
\text { use the established database of } \\
\text { candidates }\end{array}$ & $\begin{array}{l}\text { Candidates may not be satisfied } \\
\text { and the database created may not } \\
\text { be sufficient }\end{array}$ \\
\hline Recruitment agencies & $\begin{array}{l}\text { provide expertise and facilitate the } \\
\text { process of recruiting and selecting } \\
\text { employees }\end{array}$ & Consulting services are expensive \\
\hline $\begin{array}{l}\text { Recruitment agencies } \\
\text { for direct search }\end{array}$ & $\begin{array}{l}\text { Search for qualified candidates who } \\
\text { might not have shown interest in } \\
\text { any other case }\end{array}$ & $\begin{array}{l}\text { The services of consulting firms } \\
\text { are expensive and their use is } \\
\text { limited }\end{array}$ \\
\hline Job fairs & No costs and records of applicants & $\begin{array}{l}\text { Focusing on relatively routine } \\
\text { work }\end{array}$ \\
\hline $\begin{array}{l}\text { Educational } \\
\text { institutions }\end{array}$ & Enables to atract talents & $\begin{array}{l}\text { Graduate campaigns can be } \\
\text { expensive }\end{array}$ \\
\hline
\end{tabular}

Source: [12] 
Despite the advantages and disadvantages of individual recruitment methods, it is not possible to clearly determine which of the methods is most effective and will appeal to the most suitable candidates. Therefore, it is recommended to combine different methods of recruitment to make it as efficient as possible. [12]

The recruitment process is followed by the selection of the appropriate employee. The aim of the selection of employees is to recruit a candidate into the company that best meets the requirements of the vacancy. [4] While the recruitment task is to find suitable candidates, the job selection task is to assess the prospects of these candidates with regard to the job vacancies. [15] Blašková similarly to recruiting employees, perceives their selection as a "two-way communication-motivation process". [6]

\section{Survey of recruitment process of employees}

\subsection{Materials and methods}

The selected company operates in the field mechanical engineering. It is an middle size company in the field of electrical and mechanical engineering and it tends to grow in the future. An analysis of the recruitment process in the selected company was carried out in form of an interview with company's HR managers. The aim of the survey was to analyse the personnel policy in middle size company. The survey was focused on recruitment and selection of employees by the mean of the expert interviews with personalist and studying of internal documents in order to analyse the recruitment methods and proposal of effective recruitment process in the selected company.

\subsection{Survey of recruitment process of employees according to personal agency}

According to one of the most trusted recruitment surveys conducted by the ManpowerGroup carried out on a representative on 750 employers in Slovak republic have optimistic hiring plans for the second quarter of 2019. The ManpowerGroup Labour Market Index is conducted every three months in order to monitor employers' intentions to reduce or increase the number of employees during the next quarter of the year. $23 \%$ of employers of big companies (with more than 250 employers) expect an increase in the workforce. Based on this data, the Net Labour Market Index in Slovakia is $+11 \%$ for the second quarter of 2019. This means that the percentage of employers who plan to increase their employees in the second quarter of 2019 is higher than the percentage of employers who plan to reduce their employees. Results from 2018 claimed that $86 \%$ of employers stated that their number of employees will not change or will increase over the next 2-3 years as a result of automation. [16]

Most employees plan to recruit large enterprises with a Net Labour Market Index of + $20 \%$. Medium-sized enterprises also expect a favourable recruitment environment with an index of $+13 \%$. Employers in small businesses report an index of $+8 \%$ and in micro enterprises $+7 \%$. Unemployment in Slovakia is falling and foreign investment creates new jobs. It companies are increasingly complaining about the lack of suitable workers. In the required profiles, companies emphasize specialized IT, engineering and business skills, but also report a lack of candidates for unskilled positions in manufacturing and logistics. [16]

Subsequently, employers are forced to try and apply new HR strategies. They regulate the remuneration and benefits system, reorganize production, make more frequent use of part-time and flexible forms of employment, and recruit in more remote regions, even 
abroad. The best recruitment opportunities in Slovak companies are in branches of manufacturing, finance, insurance, real estate and other business services. [16]

\subsection{Survey of recruitment process of employees in selected company}

As the company expects an increase in the number of employees in the future, the work with the documents and documents of the candidates will be more difficult, and therefore the acquisition of software for maintaining the database of candidates could make it easier for the company to register them.

Recruiting and then selecting employees is a challenging process for a company to deal with. While the company manages to fill vacancies, has to strive to retain qualified and competent employees in these jobs.

On the basis of an analysis the first recruitment proposal for the company was to focus more on e-recruitment using social networks, job offering web sites, and company's own web site. An important proposal for streamlining the recruitment process is to maintain a database of candidates through appropriate software.

- Job fairs used by the company - e.g. Job Expo a Profesia days.

- References by employees - are used by the company very frequently

- Public employment agency - are used rarely, mostly in the case when other recruitment methods are not efective.

- Cooperation with middle and high schools in the region - provides the company with a supply of young manual workers. Currently the company cooperates with 2 middle schools and also with University in the region to provide master thesis tutorials.

- Recruitment agences - enables the recruitment of suitable job candidates and subsequently their selection for the vacancy in the form of personnel leasing and recruitment.

- Job advertisement - each vacancy of the company is advertised through job offering web sites - www.profesia.sk a www.istp.sk. The combination of other recruiting methods is always used.

The advantage of filling a job position from internal sources is that the company knows the employee and the employee knows the company culture. At the same time, offering a job to one's own employee increases his motivation with the employee's career growth. Of course, external resources are also important for the company because they bring new ideas, ideas and experience to the company. In the case of recruitment methods used, the company uses, in addition to traditional methods (recommendations of current employees), job portals, increasingly social network and cooperation with secondary schools in the region.

Choice between internal and external resources - the company uses internal and external resources to fill jobs. Internal resources include the company's own employees or career advancement. Applicants from the external environment are external sources. If the company's own employees meet the requirements for the vacancy, they are first offered the post. If the requirements are not met, the company must contact external sources.

Every vacancy can be advertised through the internet portals www.profesia.sk and www.istp.sk. The company can use also another method to recruit employees. Advertising through these portals, which allows the job vacancy to be presented to the general public. Combination of various recruitment methods increases the chance to find an appropriate job candidate. In the event that an undertaking wishes to fill a vacant post from external sources, it must endeavour to attract candidates in an appropriate manner by informing them of the vacancy. 


\section{Conclusion}

The employees with adequate skills are now considered to be the strongest factor in transforming the economy. Nowadays it is difficult for companies to find employees with necessary skills. The Concept of Intelligent Industry and the Action Plan as a strategic document in the Slovak Republic creating conditions for increasing competitiveness in the conditions on the labour market in the period of globalization. From a global perspective, employers are planning to increase the workforce in the future, according to the Net Labour Market Index which reflects employers' recruitment plans. According to expert interviews carried out in the selected company the mostly used methods in recruitment processes were advertisement through job offering web sites, references and use of recruitment agences' services. The combination of traditional and new e-recruitment methods could be more effective in order to find suitable job candidates for most of the vacancies in the company and to implement the software to maintain a database of candidates for company purposes.

This paper was supported by project KEGA 043ZU-4/2019.

\section{References}

1. M.C. Voicu, Using online questionnaires in the employee recruitment activity. 12th International Symposium in Management (SIM). Timisoara, Romania, 34 - 42 ( 2014)

2. S. Lorincova, The Improvement of the Effectiveness in the Recruitment Process in the Slovak Public Administration. Business Economics and Management Conference. Zvolen, Slovakia, 382-389 (2016)

3. M. Gogolova, O. Ponisciakova, K. Ivankova, The Use of External Personnel Marketing in Slovakia. Procedia Economics and Finance, 26, 131-138 (2015)

4. J. Koubek, Rizeni lidskych zdroju: Zaklady moderni personalistiky. (Management Press, Praha, 2009)

5. V. Sukalova, P. Ceniga, Current Problems of Employment Juveniles in Slovakia. Lecture Notes in Management Science, 61, 27-32 (2016)

6. M. Blaskova, Riadenie a rozvoj ludskeho potencialu. (Edis, Žilina, 2003)

7. E. Bombiak, A. Marciniuk-Kluska, Socially Responsible Human Resource Management as a Concept of Fostering Sustainable Organization-Building: Experiences of Young Polish Companies. Sustainability 11 (2019)

8. A. Kachanakova, O. Nachtmannova, Z. Joniakova, Personalny manazment.(Iura Edition, Bratislava, 2011)

9. A. Kachanakova, et al., Riadenie ludskych zdrojov. Personalna praca a uspesnost podniku. (Sprint, Bratislava, 2007)

10. P. Seemann, V. Farkasova, Coaching as a tool for improving the quality of managerial work. Globalization and its Socio-Economic Consequences. Rajecke Teplice, Slovakia, 661-669 (2015)

11. S. Alamro, H. Dogan, D. Cetinkaya, N. Jiang, K. Phalp, Conceptualising and Modelling E-Recruitment Process for Enterprises through a Problem Oriented Approach. Information 9, 9 - 11 (2018)

12. M. Armstrong, S. Taylor, Rizeni lidskych zdroju. (Grada Publishing, Praha, 2015) 
13. P.G. Bartakova, K. Guniniova, J. Brtkova, M. Hitka, Actual trends in the recruitment process at small and medium-sized enterprises with the use of social networking. Economic annals 164, 80-84 (2017)

14. M. Zakovic, Kedy vyuzit sluzby personalnych agentur? Available at: https://www.podnikajte.sk/zamestnanci-a-hr/kedy-vyuzit-sluzby-personalnych-agentur

15. R. Kocianova, Personalni cinnosti a metody personalni prace. (Grada Publishing, Praha, 2010)

16. ManpowerGroup, Index trhu práce Slovenská republika. 29 p. (2018) 